\title{
Nasib Pancasila Dalam Kurikulum Nasional
}

Oleh: Pardomuan Gultom

(dimuat di Koran Analisa edisi Selasa, 22 Juni 2021. Link e-paper: https://analisadaily.com/e-paper/2021-0622/files/assets/basic-html/index.html\#12)

Beberapa waktu yang lalu terjadi penolakan atas Peraturan Pemerintah (PP) No. 57 Tahun 2021 tentang Standar Nasional Pendidikan karena tidak memasukkan mata pelajaran Pancasila dalam kurikulum. Belakangan, akibat opini penolakan terhadap PP tersebut, Menteri Nadiem mengajukan usulan revisi kepada Presiden Jokowi.

Pertanyaannya, seberapa pentingkah Pancasila menjadi kurikulum pendidikan sehingga ia wajib dipelajari dalam pendidikan formal? Apakah hubungan Pancasila dengan pendidikan? Bagaimana kebijakan pendidikan di Indonesia dalam membuat terobosan dalam metode pembelajaran, khususnya bidang pelajaran Pancasila, sehingga tidak disebut indoktrinasi dalam upaya membentuk legitimasi kekuasaan? Lantas, Pancasila yang bagaimana yang hendak dijadikan kurikulum wajib sehingga dapat disebut mampu menjawab tantangan berbangsa dan bernegara? Untuk itu, perlu diulas korelasi antara pendidikan sebagai sebuah medium pembelajaran dengan Pancasila sebagai perangkat ideologi.

\section{Pancasila dan Pendidikan}

Pancasila sebagai dasar berdirinya Indonesia sebagai negara, tidak bisa dipisahkan dari kebijakan dalam penyelenggaraan negara, khususnya bidang pendidikan. Memformalkan Pancasila dalam bentuk kurikulum tanpa memahaminya sebagai dasar negara Indonesia yang merdeka, sebagai penuntun perjalanan kehidupan sebuah bangsa, dapat dikatakan seperti membangun menara gading atau membangun rumah di atas pasir. Tidak kokoh, mudah diterpa angin. Dalam istilah penulis, pendidikan Pancasila adalah "pendidikan filosofi kehidupan berbangsa dan bernegara". Dia tidak hanya dibatasi pada formalisme satuan pengajaran dalam lingkup sekolah dan kampus dengan model hafalan dan indoktrinasi, tetapi harus mampu membentuk karakter dan jiwa berbangsa dan bernegara yang kuat terhadap pemerintah dan rakyat.

Pendidikan Pancasila harus dianggap sebagai bagian dari menjalankan Pancasila itu sendiri. Dia tidak bisa dianggap sekedar menjalankan perintah atau amanat undang-undang atau peraturan pemerintah, karena diatas itu semua Pancasila merupakan sumbernya, ruhnya. 


\section{Konsep Pendidikan}

Seorang tokoh pendidikan, Prof. Dr. Henry Alexis Rudolf Tilaar, M.Sc.Ed. (H.A.R. Tilaar), suami dari Martha Tilaar, dalam bukunya yang berjudul "Pendidikan, Kebudayaan, dan Masyarakat Madani Indonesia" (1999), menggolongkan hakekat pendidikan dari dua jenis pendekatan, yaitu pendekatan reduksionisme dan pendekatan holistik integratif. Kedua jenis pendekatan tersebut mempunyai kesamaan di dalam memberikan jawaban terhadap persoalan hakikat pendidikan, ialah bahwa pendidikan tidak dapat dikucilkan dari proses pemanusiaan. Tidak ada suatu masyarakatpun yang dapat eksis tanpa pendidikan. Pendekatan reduksionisme melihat proses pendidikan, peserta didik dan keseluruhan perbuatan pendidikan, termasuk lembaga-lembaga pendidikan, telah menampilkan pandanganpandangan ontologis maupun metafisis tertentu mengenai hakikat pendidikan. Pandanganpandangan tersebut tidak menampilkan hakikat pendidikan secara utuh tapi sepihak berdasarkan sudut pandang yang digunakan. Dengan demikian proses pendidikan tidak dilihat secara keseluruhan.

Sedangkan pendekatan holistik integratif memandang pendidikan secara menyeluruh, tidak parsial. Hakekat pendidikan dalam pandangan ini adalah suatu proses menumbuhkembangkan eksistensi peserta didik yang memasyarakat, membudaya, dalam tata kehidupan yang berdimensi lokal, nasional dan universal. Dalam hal ini, pendidikan merupakan suatu proses berkesinambungan, proses pendidikan berarti menumbuh kembangkan eksistensi manusia yang memasyarakat dan membudaya, dimana proses bermasyarakat dan membudaya tersebut mempunyai dimensi-dimensi waktu dan ruang.

Dengan demikian, hakekat pendidikan nasional sebagai rumusan ideal (das sein) yang termaktub dalam Pasal 31 ayat (3) UUD 1945 dan Undang-Undang No. 20 Tahun 2003 tentang Sistem Pendidikan Nasional perlu membandingkannya dengan fakta empiris (das sollen) dalam bentuk perkembangan kurikulum, khususnya pendidikan Pancasila.

\section{Ganti Kurikulum}

"Ganti menteri, ganti kurikulum," seolah menjadi adagium seringnya pergantian kurikulum di Indonesia jika menteri pendidikan berganti. Ini dianggap semacam kebiasaan dalam 
perubahan sistem kurikulum nasional. Entah karena perubahan pola kebijakan kurikulum secara nasional, khususnya di bidang pendidikan Pancasila sehingga melihat Pancasila dianggap sebagai sebuah keharusan untuk mempelajarinya di setiap jenjang pendidikan ataukah terdapat kepentingan lain, misalnya kekuatan politik tertentu untuk menjadikan kurikulum Pancasila sebagai alat indoktrinasi untuk mempengaruhi kesadaran publik sebagai medium legitimasi rejim yang sedang berkuasa.

Terkait dengan hal ini, penting untuk melihat eksistensi pendidikan Pancasila dalam UndangUndang No. 20 Tahun 2003 tentang Sistem Pendidikan Nasional (UU Sisdiknas) sebagai perangkat operasional dari Pasal 31 ayat (3) UUD 1945.

Pada BAB X tentang Kurikulum, Pasal 37 ayat (1) huruf b dan ayat (2) huruf b UU No. 20 Tahun 2003 tentang Sistem Pendidikan Nasional tidak secara tegas mengatur kurikulum pendidikan Pancasila. Pada kedua pasal tersebut, hanya memuat frasa "pendidikan kewarganegaraan" bagi kurikulum wajib pada jenjang pendidikan dasar, menengah, dan pendidikan tinggi. Ketidaktegasan dalam memuat pendidikan Pancasila sebagai kurikulum wajib dalam UU Sisdiknas dapat berakibat pada tafsir yang berbeda dalam menyusun peraturan pelaksana dari undang-undang tersebut, yaitu Peraturan Pemerintah (asas lex superior derogat legi inferior). Hanya saja, di dalam bagian Penjelasan Pasal 37 ayat (1) dijelaskan bahwa Pendidikan Kewarganegaraan dimaksudkan untuk membentuk peserta didik menjadi manusia yang memiliki rasa kebangsaan dan cinta tanah air. Dan penjelasan tentang kurikulum Pendidikan Kewarganegaraan ini masih meliputi satu aspek dari 5 (lima) sila yang terkandung di dalam Pancasila, yaitu Persatuan Indonesia. Aspek lainnya tidak secara eksplisit dikemukakan dalam penjelasa pasal tersebut, baik itu aspek Ketuhanan Yang Maha Esa, Kemanusiaan yang Adil dan Beradab, Kerakyatan yang Dipimpin oleh Hikmat Kebijaksanaan dalam Permusyawaratan dan Perwakilan, maupun Keadilan Sosial bagi Seluruh Rakyat Indonesia.

\section{Kurikulum Pancasila}

Sejak Indonesia merdeka, sudah 4 (empat) kali terjadi perubahan terhadap undang-undang Sistem Pendidikan Nasional (Sisdiknas), yakni: UU No. 4 Tahun 1950 jo. UU No. 12 Tahun 1954, UU No. 2 Tahun 1989, dan terakhir UU No. 20 Tahun 2003. Dan sejak dibentuknya undang-undang yang mengatur Sisdiknas, telah terjadi pergantian nomenklatur pembelajaran 
Pancasila atau Kewarganegaraan mulai dari tahun 1957 hingga kini dengan tafsir yang berbeda pula.

Dimulai pada tahun 1957, nomenklatur yang dipakai adalah Kewarganegaraan yang membahas cara memperoleh dan kehilangan kewarganegaraan. Di tahun 1961, nomenklatur tersebut berubah menjadi Civics dengan menekankan materi sejarah kebangkitan nasional, UUD 1945, dan pidato politik kenegaraan yang berkaitan dengan tema "Nation and Character Building”.

Pada tahun 1962, Civics berganti menjadi Kewargaan Negara dan di tahun 1968 resmi ditetapkan sebagai kurikulum yang berisi materi penjabaran ideologi Pancasila, kajian tata negara, dan sejarah perjuangan bangsa. Pergantian rejim di tahun 1966, tafsir terhadap Pancasila oleh rejim Soeharto mengalami perubahan makna. Perubahan rejim tersebut membawa implikasi yang luar biasa terhadap sistem politik, tata hukum, hingga pengaturan kurikulum pendidikan.

Dengan bermodalkan Ketetapan MPRS Nomor XX/MPRS/1966 jo. Ketetapan MPR Nomor V/MPR/1973 jo. Ketetapan MPR Nomor IX/MPR/1978 yang menegaskan bahwa Pancasila dianggap sebagai sumber dari segala tertib hukum, dimana Orde Baru menafsirkan Pancasila menurut versinya, yakni asas tunggal, sehingga diluar dari penafsiran tersebut dianggap sebagai ancaman atau bahaya laten.

Pada kurikulum 1975, Pancasila versi Orde Baru melalui perangkat Pedoman Penghayatan dan Pengamalan Pancasila (P4) atau disebut Ekaprasetya Pancakarsa mulai diajarkan secara resmi di sekolah dengan nomenklatur Pendidikan Moral Pancasila (PMP) dan menjadi kurikulum pada tahun 1984. Tahun 1978, melalui Ketetapan MPR No. II/MPR/1978, P4 mendapat legitimasi untuk diajarkan pada jenjang sekolah, dimana sebelumnya hanya merupakan materi penataran wajib bagi PNS. Di tahun 1979, melalui Keputusan Presiden No. 10 Tahun 1979 tentang Badan Pembinaan Pendidikan Pelaksanaan Pedoman Penghayatan dan Pengamalan Pancasila (BP7) sebagai lembaga yang merumuskan materi P4, termasuk Lembaga Ketahanan Nasional (Lemhanas).

Di tahun 1994, PMP berubah menjadi Pendidikan Pancasila dan Kewarganegaraan (PPKn) untuk jenjang pendidikan dasar dan menengah sebagai implikasi dari undang-undang 
Sisdiknas yang baru, yaitu UU No. 2 Tahun 1989. PPKn dalam kurikulum 1994 dianggap sebagai perluasan kajian P4 melalui Kepmendikbud No. 060/U/1993 dan Kepmendikbud No. 061/U/1993.

Perubahan rejim politik dari otoritarianisme ke era reformasi turut mempengaruhi eksistensi P4 dan BP7, yang dimasa rejim Orde Baru dipergunakan sebagai perangkat tafsir rejim terhadap Pancasila hingga pada akhirnya P4 dicabut melalui Ketetapan MPR No. XVIII/MPR/1998 dan BP7 dibubarkan melalui Keputusan Presiden No. 27 Tahun 1999.

\section{Nasib Pancasila}

Lantas, bagaimana nasib Pancasila dalam kurikulum pasca Orde Baru? Setelah 23 tahun reformasi berjalan, harapan untuk merumuskan Pendidikan Pancasila dalam konsep yang murni (genuine) dengan tidak meniru atau mengadopsi pola Orde baru, masih dalam tataran wacana elite dan terdengar sayup-sayup.

Di akhir 2018 yang lalu, muncul wacana menghidupkan kembali pelajaran PMP. Persoalannya, PMP yang bagaimana, ini juga belum tuntas. Presiden Jokowi menyebutnya dengan istilah "PMP yang kekinian" (viva.co.id, 1/12/2018), dimana rencana penerapannya menurut Kemendikbud pada 2019 lalu.

Jika era pasca Orde Baru tidak ingin disebut sebagai era Pancasila-phobia, yaitu ketakutan terhadap Pancasila karena trauma masa lalu yang menjadikan Pancasila sebagai sumber sekaligus alat legitimasi kekuasaan, maka negara sebagai pihak yang paling berkepentingan terhadap tegaknya ideologi, sudah seharusnya mendudukkan Pendidikan Pancasila dalam ruang dan waktu yang tidak menariknya dari akar histori yang objektif (tercerabut dari akarnya). Dengan demikian, Pendidikan Pancasila sebagai kurikulum tidak dianggap rendah dan momok yang menakutkan bagi pelajar dan masyarakat awam sehingga ia dapat memperkuat eksistensi Pancasila itu sendiri. Bukan justu membuatnya sebagai mitos atau malah terjadi deideologisasi.

*) Penulis adalah Mahasiswa konversi Sekolah Tinggi Ilmu Hukum (STIH) Graha Kirana/Alumnus Departemen Ilmu Politik FISIP USU. 